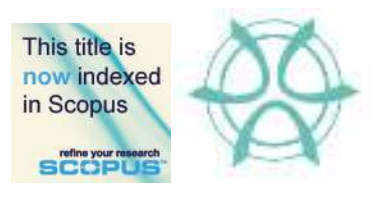

PLANNING MALAYSIA:

Journal of the Malaysian Institute of Planners

VOLUME 18 ISSUE 4 (2020), Page 259 - 270

\title{
USER AWARENESS, IMPEDIMENTS AND PROPOSED IMPROVEMENTS TO THE ONE STOP CENTRE (OSC) ONLINE 3.0 SYSTEM. CASE STUDY: MUNICIPAL COUNCIL OF SUBANG JAYA, SELANGOR, MALAYSIA
}

\author{
Siti Mazwin Kamaruddin ${ }^{1}$, Rozdiana Mohd Rosmi ${ }^{2}$, Faridah Muhamad \\ Halil $^{3}$, Alamah Misni ${ }^{4}$ Marlyana Azyyati Marzukhi ${ }^{5}$ \\ ${ }^{1,3,4,5}$ Centre of Studies for Town and Regional Planning, Faculty of \\ Architecture, Planning and Surveying \\ UNIVERSITI TEKNOLOGI MARA \\ ${ }^{2}$ Majlis Perbandaran Subang Jaya
}

\begin{abstract}
This study provides an insight into an adoption of online submission approach at a planning stage. The case study is an implementation of One Stop Centre (OSC) Online 3.0 System at a Local Authority. Local Authority is Majlis Perbandaran Subang Jaya (MPSJ) as one of the pioneers to implement this system. Currently, not all Local Authorities implement the system fully. For this study, the data collected consisted of primary and secondary data. Primary data of users' knowledge, readiness and satisfaction of the system were collected through a survey in a form of questionnaire. In contrast, secondary data were acquired from Local Government Department, MPSJ OSC Department and reliable sources, such as reports of the development plan, Local Authorities, relevant agencies, and websites. The findings indicated that almost half of the users found the system effective and successful while suggesting that there was still room for improvement relevant in shaping the alignment between technology, organisation and human factor. The resulting knowledge from this study could help to improve e-government implementation in Malaysia and could benefit other Local Authorities towards digital e-submission of plans online.
\end{abstract}

Keywords: e-submission, OSC Online System

\footnotetext{
${ }^{1}$ Senior Lecturer at UiTM. Email: sitim065@uitm.edu.my
} 
Kamaruddin, S.M., Mohd Rosmi, R., Muhamad Halil, F., Misni, A., Marzukhi, M.A.

User Awareness, Impediments and Proposed Improvements to The One Stop Centre (OSC) Online 3.0 System. Case Study: Municipal Council of Subang Jaya, Selangor, Malaysia

\section{BACKGROUND}

One-Stop Centre (OSC) Online 3.0 System is an electronic system for submission applicants to improve a delivery system at a Local Authority. This system is in line towards positioning Malaysia into the top 20 World Bank Ranking for Ease of Doing Business among 190 countries in the world (CIDB, 2019). Dealing with Construction Permit (DCP) is one of the ratings used by World Bank to determine the ranking. Digital or e-government provides information and online transaction service to citizens in the state by government. E-government is an essential application of information technology for the functioning of the government to enhance the delivery of public service to citizens and other individuals, as well as organisational consumers of the government service.

Since 2011, the OSC Online 3.0 System has been introduced to all Local Authorities in Malaysia. The module of the system contains e-submission and e-processing. The application is mandatory for every Local Authority to use. However, to date, only a few Local Authorities use the system fully. Local Authorities (LAs) that use the system implement e-submission for Planning Approval Integrated with Infrastructure Plan and Building Plan or Planning Approval with Building Plan or Planning Approval for Material Change of Use. Relevant stakeholders, who use the system are Local Authority, Professional Submission Person (PSP), External Technical Department or Agency, and Owner (Public). In line with Eleventh Malaysia Plan (RM Ke-11) that emphasises on broader adoption of Information and Communications Technology (ICT), the new system shall be based on an open source, which is fully integrated with an existing system, as well as utilises cloud computing and customer-centric transaction processing. This study provides an insight into the adoption of ICT approach at the planning stage using the case study of OSC Online 3.0 System at Majlis Perbandaran Subang Jaya (MPSJ). MPSJ is a Local Authority and one of the pioneer implementers of this system. The findings can help in informing strategies to enhance the municipality's delivery system of submission.

\section{E-GOVERNMENT IN MALAYSIA}

Malaysia started the e-government initiative more than 17 years ago since announcing Multimedia Super Corridor (MSC) project. In keeping with worldwide trends, Malaysia has joined the bandwagon by introducing its egovernment initiative as one of the flagships for MSC. In 2010, Malaysia government embarked on the transformation programme that would not only affect the public delivery service through a concept of connected government that addresses citizen centricity (EPU, 2015).

Under one of seven MSC flagships which were launched in August 1996, e-government aimed to improve the convenience, accessibility and quality of delivery government service, as well as improve the information flows and 
processes. This was done to increase the speed and quality of policy development, coordination and enforcement (MAMPU, 2010). Under the Tenth Malaysia Plan, which spanned between the years 2011 until 2015, it was shown that $77 \%$ out of 13,483 government service had been provided online by the government of Malaysia. This portrayed the huge investment made to ensure e-government a success (EPU, 2015).

\section{EFFECTIVENESS CRITERIA OF E-GOVERNANCE}

Several studies have been conducted on information technology effectiveness and adoption (Petroni \& Cloete, 2005; Tarhini et al., 2015) and overcoming barriers (Meijer, 2015). Karavasilis et al. (2010) elucidated that based on theory of reasoned action, a person's actual system usage is mostly influenced by his or her behavioural intentions towards a usage. The person's actual system storage is influenced by the perceived usefulness and ease of use of the system. Petroni and Cloete (2005) argued that the effectiveness criteria of e-governance include the attainment of stakeholders towards their goals and the responsiveness of the administration. In this study, the perceptions, as well as opinions of submitting persons and technical staff in using this system at the planning stage can shed light on the issue of incompetency of the system management itself or difficulties faced by the system users on the submission, e-processing and approval notification. The case of a Local Authority's implementation of the system and its stakeholders' opinions can be used to provide an insight into the e-governance approach to enhance the municipality delivery system by identifying the potential areas for improvement and monitoring process. The resulting knowledge from this study could help to improve e-government implementation in Malaysia and other developing countries.

\section{LOCAL GOVERNMENT'S EFFECTIVENESS DELIVERY SYSTEM}

Effectiveness can be defined as a level, in which something intended is successful in producing desired results. Meanwhile, efficiency is defined by achieving maximum productivity by appropriately using available resources (Mariana et al., 2014). Nevertheless, effectiveness and efficiency are both popular words in the service delivery system used to evaluate service delivery performances. Bourn (2006) summarised that something is effective if it is adequate to accomplish a purpose and produce the intended or expected result. On the other hand, it is efficient if it performs or functions in the best possible manner with the least waste of time and effort. Bourn (2006) mentioned that "Being effective is about doing the right things, while being efficient is about doing things in the right manner".

The effectiveness and efficiency of service delivery among Local Authorities have been the priority of federal and state governments of Malaysia. 
Kamaruddin, S.M., Mohd Rosmi, R., Muhamad Halil, F., Misni, A., Marzukhi, M.A.

User Awareness, Impediments and Proposed Improvements to The One Stop Centre (OSC) Online 3.0 System.

Case Study: Municipal Council of Subang Jaya, Selangor, Malaysia

The effectiveness and efficiency of service delivery are parallel with the government aspiration towards a developed nation by the year 2020. Mariana et al. (2014) explained that the vital contribution delivered by the local government is providing essential service to everyone without discrimination, especially those who currently have minimal access or no access to the service. Thus, effective and efficient delivery is considered as an essential element of the local government's responsibility. This makes this sphere of government closest to the people.

\section{CONTENT OF ONLINE SYSTEM}

Electronic government has the processes and structures related to the electronic delivery of government service to the public. Zhiyuan (2002) stated that egovernment is functionally dependent on an association between private partnership, namely, executive, policymakers, administration, and civil service. Furthermore, e-government is dependent on an association between external partnership, namely, Central or Federal Government and State, Country or Local Government.

\section{THE INDICATORS OF SUCCESSFUL ONLINE SYSTEM}

There are three (3) indicators contributing to the success of an online system, which are organisation factors, as well as technology and people factors (Prybutok et al., 2008). The organisational factors comprise issues that are internal to a typical public sector organisation, as well as they influence the adoption and implementation of e-government in those organisations. Strong political leadership is claimed to play a significant role in putting e-government into the agenda and making it a success (Al-Tameem et al., 2006; Furuholt \& Wahid, 2008; Gil-Garcia \& Pardo, 2005).

In the context of inter-organisational, Garfield (2000) argued that the presence of internal leadership in each participating organisation is very important as the existence of system-wide leadership is not always sufficient to provide the necessary strategic direction for the initiative. Moreover, the internal leadership in each participating organisation views effective strategic leadership as moderating the espoused relationship between organisational resources investment and transformative e-government development. Governments require committed and knowledgeable leaders who will enable the governments to carry out their strategic roles and tasks.

Muhammad (2014) described that e-government initiatives require a considerable degree of technical competence through maintaining infrastructure, integrating distributed systems and providing necessary applications to ensure efficient implementation. The technological infrastructure is a significant 
PLANNING MALAYSIA

determinant factor that shapes the success or failure of worldwide e-government initiatives.

On the other hand, failures of e-government initiatives around the world have been linked to poor technological infrastructure. Unreliable information technology (IT) infrastructure in public sector organisations will degrade egovernment performance. Governments view a lack of technical infrastructure as a significant barrier to the development of the public sectors' capabilities to provide online service and transactions (Bonham et al., 2001). Inadequate IT infrastructure is mainly due to the lack of consistent and reliable electricity, telecommunications, Internet connectivity, as well as low accessibility to the necessary applications (Muhammad, 2014).

\section{METHODOLOGY}

Upon identification of the study background and problem, the aim of the study was formed. Next, the review of the existing literature focusing on user adoption of online e-governance or e-submission was conducted. Following that, data were gathered on variables of interest. Data types were segmented into two categories, which included primary data and secondary data. Primary data of users' knowledge, readiness and satisfaction of the system were collected through a questionnaire survey.

On a contrary, secondary data were acquired from Local Government Department, Ministry of Housing and Local Government (MHLG), MPSJ OSC Department, and reliable sources, such as reports of development plan, Local Authorities, relevant agencies, and websites. Survey in a form of questionnaire was distributed to three primary users of the system, namely, Professional Submission Persons or Submission Person (PSP/SP), Technical Department, including internal and external department, as well as MPSJ OSC Department, including non-government, professional boards or agencies related to the egovernment initiative. Questionnaire to the respective users included information about the challenges faced by PSP/SP, Internal and External Technical Department, OSC Department itself, and other agencies.

The respondents for e-submission at the planning stage under OSC Online 3.0 System consisted of the professional people, the owners, and the representatives of the project owners. Meanwhile, the respondents for the reprocessing under OSC Online 3.0 System were the key people who were directly involved with the system starting from applicants' identification data (ID) registration to screening the applications submitting by Principal Submitting Person/Submitting Person (PSP/SP) and Technical Expert Comments. The key people directly involved with the system were MPSJ OSC Secretariat, Technical Internal Department, and External Technical Department. The respondents were selected based on the main criteria that each had experience using the online 
Kamaruddin, S.M., Mohd Rosmi, R., Muhamad Halil, F., Misni, A., Marzukhi, M.A.

User Awareness, Impediments and Proposed Improvements to The One Stop Centre (OSC) Online 3.0 System.

Case Study: Municipal Council of Subang Jaya, Selangor, Malaysia

submission at any stage of the online process submission. The respondents were identified and invited by the research team to participate in answering the questionnaire voluntarily (see Tables 1 and 2).

Table 1: Category of Respondents for e-Submission

\begin{tabular}{|l|l|r|r|}
\hline No. & Category & Frequency & $\begin{array}{l}\text { Percentage } \\
\text { cas }\end{array}$ \\
\hline 1. & Owner & 3 & 5 \\
\hline 2. & Representative & 6 & 10 \\
\hline 3. & Town Planner & 11 & 16 \\
\hline 4. & Architect & 30 & 48 \\
\hline 5. & Engineer & 10 & 16 \\
\hline 6. & Landscape Architect & 3 & 5 \\
\hline & & 63 & 100 \\
\hline
\end{tabular}

Twenty-eight (28) survey forms were distributed to the respective technical agencies, including eight (8) officers at OSC Department who were directly involved with OSC Online System. Another twenty (20) respondents were divided into Internal Department and External Department. The details of the selected respondents for e-processing were shown in Table 2 below: -

Table 2: Category of Respondents

\begin{tabular}{|l|l|c|c|}
\hline No. & Category & Frequency & Percentage (\%) \\
\hline 1. & OSC Secretariat & 8 & 28.5 \\
\hline 2. & Internal Department & 8 & 28.5 \\
\hline 3. & External Department & 12 & 43.0 \\
\hline & Total & $\mathbf{2 8}$ & $\mathbf{1 0 0 . 0}$ \\
\hline
\end{tabular}

\section{ANALYSIS AND FINDINGS}

Analysis of system effectiveness and user adoption in this study referred to the users' readiness, awareness of the system and their satisfaction level. These criteria were adapted from the various literature related to online submission (Meijer, 2015; Petroni \& Cloete 2005). 
Table 3: Analysis of System Effectiveness and User Adoption

\begin{tabular}{|c|c|c|c|c|c|}
\hline \multicolumn{6}{|l|}{ Readiness Analysis } \\
\hline & First Timer & $\begin{array}{l}\text { Established } \\
\text { User }\end{array}$ & $\begin{array}{l}\text { Percentage } \\
(\%)\end{array}$ & & Total \\
\hline $\mathrm{PSP} / \mathrm{SP}$ & $18(28 \%)$ & $45(72 \%)$ & 72 & & 63 \\
\hline OSC Secretariat & 0 & 8 & 100 & & 8 \\
\hline Internal Department & 0 & 8 & 100 & & 8 \\
\hline External Department & 2 & 10 & 83 & & 12 \\
\hline \multicolumn{6}{|c|}{ Users Frequency Usage Mode using OSC Online } \\
\hline & $\begin{array}{l}20 \text { Days/ } \\
\text { Month }\end{array}$ & $\begin{array}{l}\text { 6-10 Days/ } \\
\text { Month }\end{array}$ & $\begin{array}{l}\text { 2-5 Days/ } \\
\text { Month }\end{array}$ & $\begin{array}{l}\text { 0-1 Days/ } \\
\text { Month }\end{array}$ & Total \\
\hline $\mathrm{PSP} / \mathrm{SP}$ & 4 & 14 & $36(57 \%)$ & 9 & 63 \\
\hline OSC Secretariat & 8 & 0 & 0 & 10 & 8 \\
\hline Internal Department & 2 & 6 & 0 & 0 & 8 \\
\hline External Department & 4 & 4 & 2 & 2 & 12 \\
\hline \multicolumn{6}{|c|}{ Users Ease of Setting Up Identification Data Online } \\
\hline & Yes & $\begin{array}{l}\text { Percentage } \\
(\%)\end{array}$ & No & $\begin{array}{l}\text { Percenta } \\
\text { ge }(\%)\end{array}$ & Total \\
\hline $\mathrm{PSP} / \mathrm{SP}$ & 47 & 76 & 15 & 26 & $63(100 \%)$ \\
\hline \multicolumn{6}{|c|}{ Users Ease of Project ID Approval } \\
\hline $\mathrm{PSP} / \mathrm{SP}$ & Immediately & 3-5 Days & $\begin{array}{l}\text { More than } \\
5 \text { days }\end{array}$ & \multirow[t]{2}{*}{ Total } & \multirow[t]{2}{*}{$63(100 \%)$} \\
\hline & $11(18 \%)$ & $39(62 \%)$ & $12(20 \%)$ & & \\
\hline \multicolumn{6}{|c|}{ Users Awareness of Registration Guideline is at MPSJ Website } \\
\hline & Yes & $\begin{array}{l}\text { Percentage } \\
\text { (\%) }\end{array}$ & No & $\begin{array}{l}\text { Percenta } \\
\text { ge }(\%)\end{array}$ & Total \\
\hline $\mathrm{PSP} / \mathrm{SP}$ & 59 & 95 & 4 & 5 & $63(100 \%)$ \\
\hline \multicolumn{6}{|c|}{ Users Satisfaction level of Consultation Counter Services Quality } \\
\hline \multirow[t]{2}{*}{$\mathrm{PSP} / \mathrm{SP}$} & Excellent & Good & Satisfied & Others & Total \\
\hline & $48(77 \%)$ & $12(18 \%)$ & $3(4 \%)$ & $1 \%$ & $63(100 \%)$ \\
\hline \multicolumn{6}{|c|}{ Users Accessibility To The Checklist Form } \\
\hline & $\begin{array}{l}\text { MPSJ } \\
\text { website }\end{array}$ & JKT website & $\begin{array}{l}\text { OSC } \\
\text { counter }\end{array}$ & & Total \\
\hline $\mathrm{PSP} / \mathrm{SP}$ & $58(93 \%)$ & $4(6 \%)$ & $1(1 \%)$ & & $63(100 \%)$ \\
\hline \multicolumn{6}{|l|}{ Online Submission } \\
\hline \multicolumn{6}{|c|}{ Users Awareness of the Flow Chart Process } \\
\hline & Yes & $\begin{array}{l}\text { Percentage } \\
(\%)\end{array}$ & No & $\begin{array}{l}\text { Percenta } \\
\text { ge }(\%)\end{array}$ & Total \\
\hline $\mathrm{PSP} / \mathrm{SP}$ & 48 & 77 & 15 & 23 & $63(100 \%)$ \\
\hline \multicolumn{6}{|l|}{$\begin{array}{l}\text { Users } \begin{array}{l}\text { Awareness of } \\
\text { two stages of }\end{array} \\
\text { Checking (Revised } \\
\text { Process) }\end{array}$} \\
\hline & Yes & $\begin{array}{l}\text { Percentage } \\
(\%)\end{array}$ & No & $\begin{array}{l}\text { Percenta } \\
\text { ge }(\%)\end{array}$ & Total \\
\hline $\mathrm{PSP} / \mathrm{SP}$ & 36 & 57 & 27 & 43 & $63(100 \%)$ \\
\hline \multicolumn{6}{|c|}{ Users Awareness of Multilayer Comments } \\
\hline & Immediately & 3-5 Days & $\begin{array}{l}\text { More than } \\
5 \text { days }\end{array}$ & & Total \\
\hline & $17(27 \%)$ & $41(65 \%)$ & $5(8 \%)$ & & $63(100 \%)$ \\
\hline
\end{tabular}


Kamaruddin, S.M., Mohd Rosmi, R., Muhamad Halil, F., Misni, A., Marzukhi, M.A.

User Awareness, Impediments and Proposed Improvements to The One Stop Centre (OSC) Online 3.0 System. Case Study: Municipal Council of Subang Jaya, Selangor, Malaysia

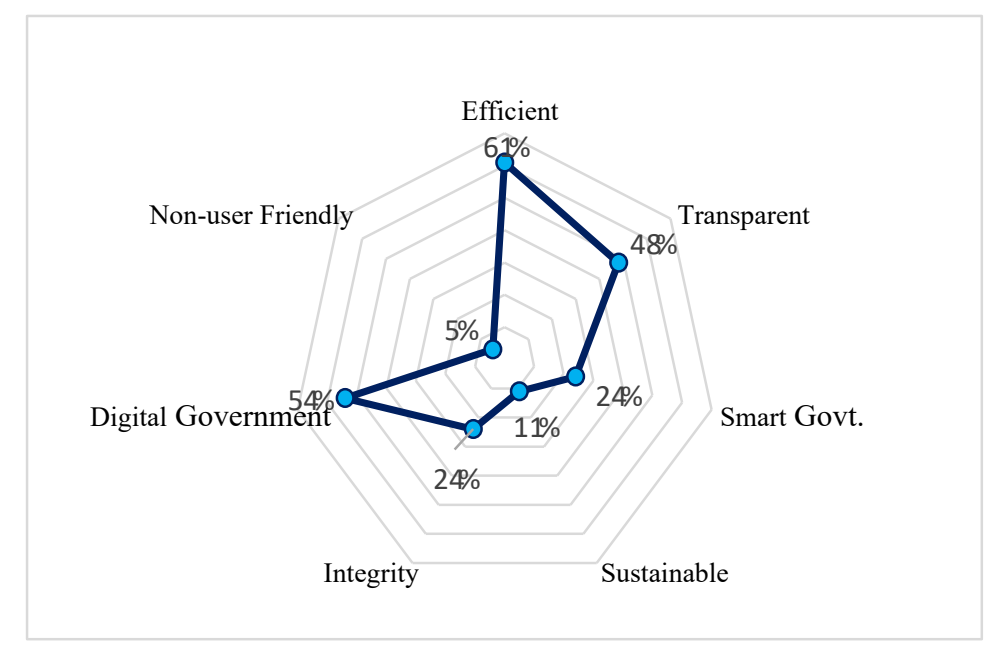

Figure 1: Users Opinion of OSC Online 3.0 System Quality Criteria

The respondents (PSP/SP) could select more than one quality criterion to describe the system. The data revealed that "Efficient" ranked the highest, as users perceived that it was an efficient way for submission online followed by "Digital Government". Nevertheless, the third highest rank was "Transparent" with users perceiving that the system was transparent in the process, followed by "Smart government" and "Integrity".

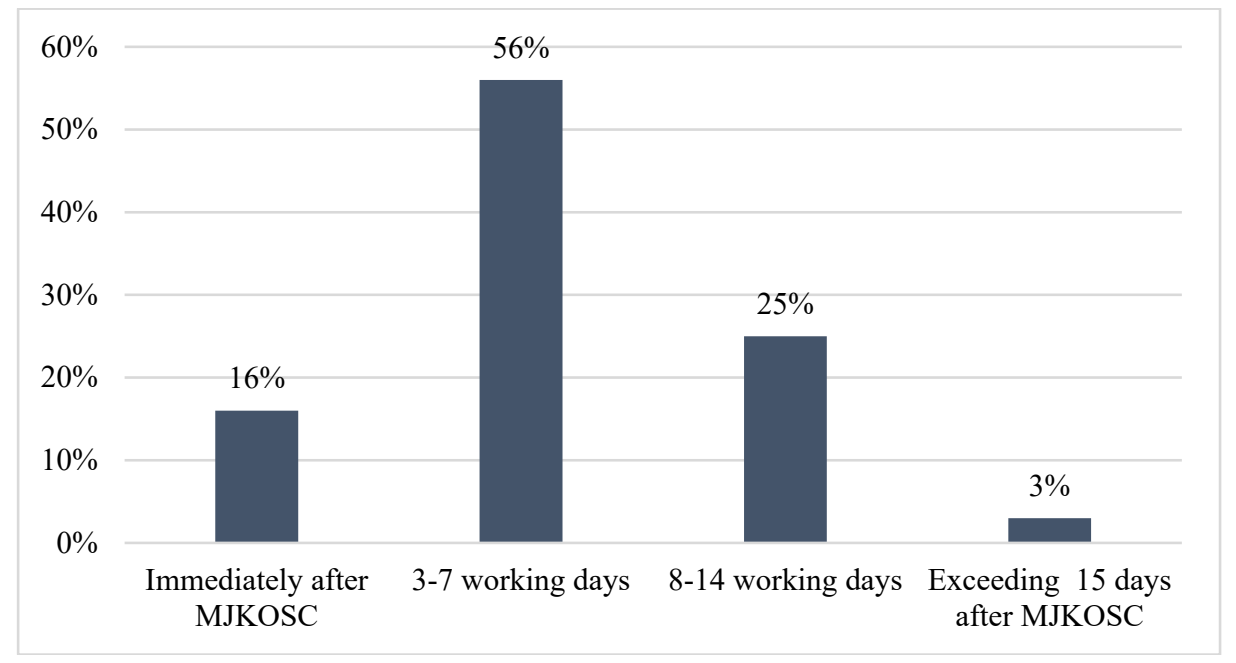

Figure 2: Duration of time in receiving result acknowledgement letter 
As shown in Figure 2, 56 per cent of PSP/SP received the results from OSC Secretariat from three to seven working days. About 25 per cent of the users obtained a letter of acknowledgement in 8 to 14 days, and 5 per cent of the users received the results after 15 days. Only 16 per cent of the users received the results immediately after post OSC secretariat meeting. Besides that, PSPs reported that they had to call OSC Counter to check their online submission status because sometimes, they could not communicate with the person in charge.

The study also found that about 70 per cent of the respondents agreed that the existing system lacked self-checking and monitoring system, in which the application tracking could not be traced effectively. This incident occurred since the system was not linked to users' email notification. This exposed a weakness of OSC Online System as the public had to resort to other practical means to check their status of the submission.

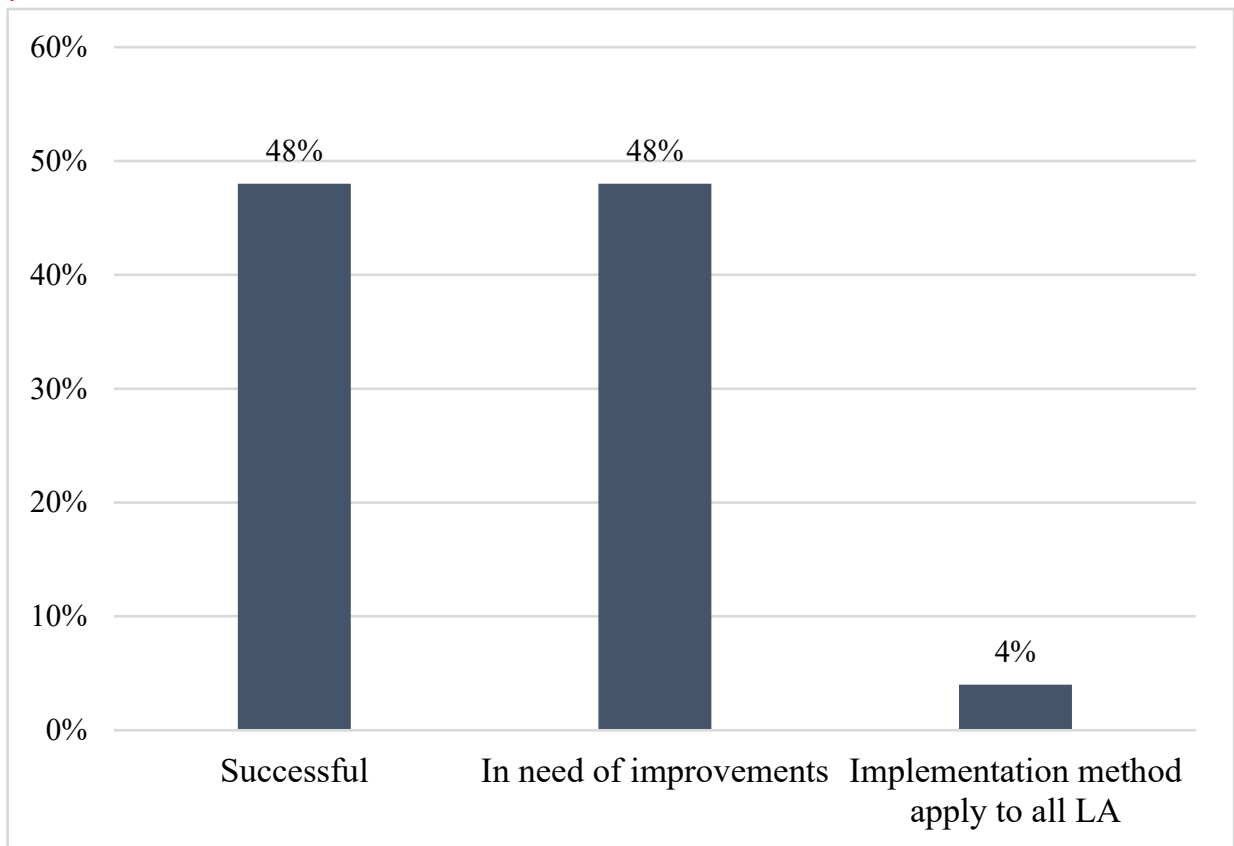

Figure 3: Overall Comments of e Submission

\section{PROPOSED IMPROVEMENTS}

Several proposed improvements are suggested. These improvements focus in shaping the alignment between technology, organisation and human factor. A challenge to OSC Secretariat is to improve the transparency of work distribution among technical staff. It is recommended that for efficiency, several tasks should be fairly distributed. These tasks are seen as important as the staff multitask 
Kamaruddin, S.M., Mohd Rosmi, R., Muhamad Halil, F., Misni, A., Marzukhi, M.A.

User Awareness, Impediments and Proposed Improvements to The One Stop Centre (OSC) Online 3.0 System. Case Study: Municipal Council of Subang Jaya, Selangor, Malaysia

activities, such as processing online submission, duty counters to receive processing fees or payment and preparing the submission for distribution purpose to other technical departments.

Ministry of Housing and Local Government (MoHLG) can produce a simplified submission application that can be accessed through mobile and desktop. The application can include OSC Checklist that is available in the system and auto-generated when PSP chooses the types of submission. The checklist link must be editable to PSP/SP to upload the necessary documents. The auto-generated checklist helps to standardise the documents needed to be uploaded for submission and processing. Moreover, the system providers should enable digital signature for the validity of every drawing plan submitted. A further recommendation in the system to ease the users towards e-submission is enabling accessibility to online banking with an automatic fee calculation for standard submission. Recommendations in the system to ease the users for both the OSC Secretariat technical staff in e-processing and PSPs include enabling automatic notification to PSP/SP as an acknowledgement of submission, as well as status through the email and other applications.

Another recommendation in the system to improve efficiency among processing department, internal department and external agencies technical staff is enabling a direct notification to the staff's official email. The notification can be sent in two stages: on initial submission by PSP, with the second notification automatically sent three (3) days before the stated two weeks' due date for technical comments. In support of the digital movement, a notification can also be relayed in other mediums, such as Short Message Service (SMS) or WhatsApp application. The system can also auto-disable for any comments from the technology that does not comply with the due date and as a record for further actions. Furthermore, another recommendation in the system includes enabling ease of information sharing between the departments for a compilation of paperwork. This is because the system can include a friendly function of emeeting that records the proceedings of the e-meeting.

\section{CONCLUSION}

This study provides an insight into some of the impediments faced by the users of OSC Online System 3.0 using a case study of one of the implementing pioneers, which is Majlis Perbandaran Subang Jaya. This system is introduced to facilitate PSPs and users from the technical department in the several stages of esubmission and e-processing. The findings of this research are essential towards identifying improvements for OSC Online System as these findings comprise a solution-based approach towards minimising wastage of resources, as well as promoting increased accessibility, speed and transparency of the government's service. 


\section{ACKNOWLEDGMENT}

The authors would like to thank Faculty of Architecture, Planning and Surveying, Universiti Teknologi MARA (UiTM) and LESTARI Grant (Universiti Teknologi MARA) (600-IRMI 5/3/LESTARI (053/2018) for funding this research.

\section{REFERENCES}

Al-Tameem, T., Zairi, M., \& Al Shawi, S. (2006). Critical success factors of egovernment: A proposed model for e-government implementation. 2006 Innovation in Information Technology, 1-5.

Bonham, G. M., Seifert, J., \& Thorson, S. (2001). The transformation potential of egovernment: The role of political leadership. Pan European International Relations Conference, 4.

Bourn, J. B. (2006). Philosophy and action in politics. Political Studies, 13(3), 377-385.

CIDB (2019). The Construction Industry Transformation Programme (CITP). Kuala Lumpur.

Economic Planning Unit (2015). Government Transformation Programme (GTP). Putrajaya: The Economic Planning Unit Prime Minister Office.

Furuholt, B., \& Wahid, F. (2008). E-government challenges and the role of political leadership in Indonesia: The case of Sragen. In Proceedings of the $41^{\text {st }}$ Hawaii International Conference on System Sciences (HICCS, 2008).

Garfield, M. (2000) Critical success factor for the state telemedicine policy. In Proceedings of the $6^{\text {th }}$ Americas Conference on Information Systems.

Gil-Garcia, J. R., \& Pardo, T. A. (2005). E-government success factors: mapping practical tools to theoretical foundations. Government Information Quarterly, 22, 187-216.

Karavasilis, I., Zafiropoulos K., \& Vrana V. (2010). Extending TAM to understand egovernance adoption by teachers in Greece. World Knowledge of Summit Society, 57-68.

MAMPU (2010). Empowerment Local Authority Delivery System through ICT. Putrajaya: Prime Minster Office.

Mariana, M. O., Syahriah, B., Nurul, I. M. B., \& Nor, Z. H. (2014). Government delivery system: Effectiveness of local authorities in Perak. Procedia-Social and Behavioral Sciences, 153, 452-462.

Meijer, A. (2015). E-governance innovation: Barriers and strategies. Government Information Quarterly, 32(2), 198-206, ISSN 0740-624X, https://doi.org/10.1016/j.giq.2015.01.001.

Muhammad (2014). Managing Successful E- Government Implementation: case of ESyariah In Malaysia. (Unpublished Doctoral dissertation.) United Kingdom, UK: University of Warwick.

Petroni G., \& Cloete, F. (2005) New Technologies in Public Administration (Vol. 28), The Netherlands: IOS Press.

Prybutok, V. R., Zhang, X. and Ryan, S. D. (2008). Evaluating leadership, IT quality and net benefits in an e-government environment. Information and Management, 45, 143-152. 
Kamaruddin, S.M., Mohd Rosmi, R., Muhamad Halil, F., Misni, A., Marzukhi, M.A.

User Awareness, Impediments and Proposed Improvements to The One Stop Centre (OSC) Online 3.0 System.

Case Study: Municipal Council of Subang Jaya, Selangor, Malaysia

Tarhini, A., Mgbemena, C., Trab, M. S. A., Masa'deh, R. (2015). User adoption of online banking in Nigeria: A qualitative study. The Journal of Internet Banking and Commerce, 20, 132.

Zhiyuan, F. (2002). E-government in digital era: Concept, practice and development. International Journal of the Computer, the Internet and Management, 10(2), 1-22.

Received: $15^{\text {th }}$ May 2020. Accepted: $1^{\text {st }}$ Sept 2020 